\title{
Digital Transformation of the Ukrainian Economy: Digitization and Transformation of Business Models
}

\author{
Viktoriia Yanovska ${ }^{1}$, Olha Levchenko ${ }^{1}$, Viktoriia Tvoronovych $^{1}$, and Anastasiia Bozhok $^{1}$ \\ ${ }^{1}$ State University of Infrastructure and Technologies, Department "Economics, marketing and business \\ administration”, Kyrylivska str. 9, Kyiv, 04071, Ukraine
}

\begin{abstract}
The studies are devoted to the transformational processes associated with digitalization, which takes place in the Ukrainian economy. Economic development is impossible without widespread introduction and full use of the digital technologies. The rate of digital innovation is growing every year. The transformation of the landscape of interpersonal connections and economic relations leads to the digitalization of the operational processes and the change in business models, which generally results in large-scale digital transformation of companies. Meanwhile, it should be noted that the digitization and transformation processes of business models, taking place mainly at the level of private and state enterprises, are expanding to the level of government and have a significant impact on the competitiveness of the economy. Today, there is a significant number of projects of digital transformation in Ukraine. The general idea is to create a unified digital communication system. It is nice to note that not only private companies but also state structures have joined this system, which testifies to their interest in self-development and the desire to keep up with the modern technologies, focusing on clients.
\end{abstract}

\section{Introduction}

The modern economic development is impossible without widespread introduction and full use of the digital technologies. The rate of digital innovation is growing every year. The number of end-users is increasing. Hootsuite's Global Digital 2019 research suggests that, on average, more than a million new Internet users appear on the Internet every day. In 2019, the number of: (1) mobile users has been increased by 100 million (or 2\%) to 5.11 billion; (2) active Internet users - by 366 million (or 9\%) to 4.39 billion; (3) users of social networks - by 288 million (or $9 \%$ ) to 3.48 billion; persons using social networks on mobile

\footnotetext{
${ }^{1}$ Corresponding author: nastya.bozhok@gmail.com
} 
devices - by 297 million (or 10\%) to 3.26 billion [1]. In October 2018, the number of active users of Internet resources in Ukraine was $63 \%$ of the population. According to Factum Group Ukraine, $70 \%$ of users constantly use smartphones to access the Internet, $36 \%$ laptop, 3\% - working computers [2]. The transformation of the landscape of interpersonal connections and economic relations leads to the digitalization of the operational processes and the change in business models, which generally results in large-scale digital transformation of companies.

\section{The Main Directions of Digital Transformation}

At present, many scientific and applied researches of foreign specialists are devoted to digital transformation, but the Ukrainian scientists have begun to deepen in the study of the mentioned problems relatively recently. Globally recognized digital expert David Rogers (2016) argues that digital transformation is not about updating your technology, but about upgrading your strategic thinking [3]. But transformation of business models in most cases leaves behind the research area, since the main interest is aimed at the introduction of the technological innovations. According to the data of 2019, in Ukraine, technological landscape 4.0 included 62 companies, which are distributed in 16 segments +1 on system integration, which is the most numerous (21 companies). Among the technological segments that include IoT Plaform, Blockchain, IoT devices, Drones, Robotics, Machine Vision, Mobile Technologies, etc., the Big data/AI/ML segment (15 companies) is leading, the second largest is IoT devices segment (12 companies), and the third largest is AR/VR (11 companies) [4].

Meanwhile, it should be noted that the digitization and transformation processes of business models, taking place mainly at the level of private and state enterprises, are expanding to the level of government and have a significant impact on the competitiveness of the economy. On the one hand, digital transformation, by creating the conditions for gathering the necessary information about the business environment and operating activities, making informed decisions and their rapid implementation, is inevitable and economically feasible (contributes to lower costs, improved customer service, business scalability, development and flexibility of the companies) [5]. As a result, the prospect of the current opportunities for the future of business, the state and consumers is changing. On the other hand, it requires from the same companies the creation of flexible organizational conditions and the introduction of digital business models necessary for rapid adaptation to the changing realities of the dynamic ecosystems.

According to current studies (IMD, World Digital Competitiveness (WDC), 2018) [6], the level of digital competitiveness, which evaluates the ability of countries to implement and explore digital technologies, depends on three main factors: knowledge (with subfactors: talent, training and education, scientific concentration), technologies (normative legal base, capital, technological basis), readiness for the future (adaptive relations, business flexibility, IT integration). According to the world digital competitiveness ranking, Ukraine occupies $58^{\text {th }}$ place (index 51,292) out of 63 countries, though in 2017 it occupied the $60^{\text {th }}$ place. At the same time, the factor of knowledge $-39^{\text {th }}$ place, and the factors of technology and readiness for the future $-61^{\text {st }}$ place, indicating a sufficiently high potential.

According to the Global Competitiveness Index [7], compared to 2017, Ukraine improved by six places, but the rating methodology has changed. Some positions dropped over the year, and Ukraine ranked $83^{\text {rd }}$ out of 140 . Ukraine scored the most points for such components as Skills ( $45^{\text {th }}$ place), Market Size ( $47^{\text {th }}$ place), Infrastructure $\left(57^{\text {th }}\right.$ place) and Innovative Capacity ( $58^{\text {th }}$ place). And by the indicator "level of electrification" even managed to take the first place. The components that pull Ukraine down are Macroeconomic Stability $\left(131^{\text {st }}\right.$ place $)$, Financial System $\left(117^{\text {th }}\right.$ place $)$ and Institutions $\left(110^{\text {th }}\right.$ place). 
Because of such low indicators of Ukraine's rating and in order to stimulate the economy and attract investments, transform the domestic industries into competitive and efficient ones, solve the digital gap issue, create new opportunities for human capital, develop innovative, creative and digital industries and business; develop export of digital products and services (IT outsourcing), the Cabinet of Ministers of Ukraine approved the Concept for the Development of the Digital Economy and Society of Ukraine for 20182020 [8].

The adoption of the Concept was preceded by a presentation in late 2016 of the Digital Agenda 2020 - a document aimed at endorsing priority areas, initiatives, digitalization projects by 2020 [9], developed under the Europe 2020 Strategy with the objective to create additional opportunities of implementation of Ukraine's development together with the EU. It is this document that initiated the principles of Ukraine's development in digital space on the state level and became the basis for the development of the digital economy. In accordance with it, the basic principles of digitalization of Ukraine are as follows:

- Any member of the society has the right to access digital technology, the Internet of knowledge;

- Digital technologies should become an instrument for achieving certain goals of development of various sectors of the national economy;

- Possibility of additional attraction of investments;

- Creation of primarily Ukrainian content to meet national needs, which will promote economic development not only, but also social and cultural one;

- Integration of Ukraine into the European and global communication system;

- Need to develop standards for digitalization, which will allow to increase competition and reduce expenses and cost of production;

- Compliance with the international standards in the financial area;

- Avoiding the orientation of the digital economy to private business only;

- Need to provide cyber security measures at the state level;

- Protection of the rights of Internet consumers; and

- The government should occupy one of the key places in the preparation, development and promotion of national digital strategies.

Today there are numerous digital transformation projects in Ukraine. The general idea is to create a unified digital communication system. It is nice to note that not only private companies but also state structures have joined this system, which testifies to their interest in self-development and the desire to keep up with the modern technologies, focusing on clients. In particular, the Digital Transformation Road Map in Agri-Food Project [10] has been created, which helps food and processing industry enterprises to be engaged in global processes of digital transformation.

Taking into account the above, it should be noted that the development of IT technologies has a constant tendency to increase and by 2025 will double twice, as shown in Fig. 1

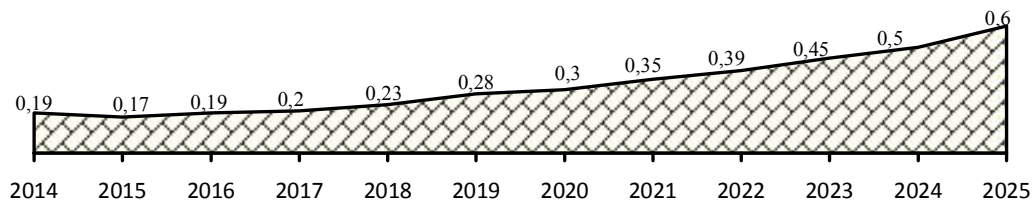

Fig. 1. Forecast of the dynamics of development of IT-services in Ukraine, billion dollars (the forecast is compiled according to [11]).

\section{Opportunities and threats}


Given the objective nature of the processes of digitization and transformation of business models, the ambiguity of future results should be taken into account. On the one hand, digital transformation processes are preceded by the emergence of additional opportunities, which, according to the results of the SWOT analysis, include the possibility of saving money and obtaining additional profits, increasing the competitiveness of products and companies, simplifying work with the database, building a positive image, increasing customer demand to the brand. On the other hand, there are threats to data security and cyber attacks. The strong points of these processes are the constant development in social networks, primarily due to the advertising of products or the company as a whole, as well as simplification of sales procedures (meeting the needs of consumers at anytime and anywhere). The weaknesses are imperfect data privacy systems, software imperfections (program crashes), temporary lack of proper computer and software. The weak sides of Ukraine as a whole include inadequate protection of intellectual property rights, the level of development of banks and financial services, rather high investment risks, the need to strengthen cybersecurity and the presence of piracy, the strong sides - the relative ease of starting a business, the rather high speed of Internet connections, e-democracy, the use of large data and the relatively high quality of training. In Ukraine, the ratio of teachers and students, many women researchers and graduates of scientific specialties are important.

In the process of digital transformation, digitalization and business model changes, the company has to go through several stages, namely, in general, to determine what to strive for and clarify the development strategy (future interaction with customers, methods of competition, tools for working with large data, directions and pace of innovation, it is possible even to change the basic values), then digitize marketing and automate the operational processes.

It should be understood that digital transformations would require personnel changes. According to the research [12], in the coming years, business structures around the world will face the situation of so-called personnel famine. A survey by more than 600 senior executives conducted by the Boston Consulting Group (BCG, 2017) showed that many companies nowadays lack the skills of qualified professionals to address key technological challenges. Trying to form a pool of "digital talents", hire, educate and retain highly skilled specialists in the business areas, develop new digital skills from the existing personnel. During the study, interviews were conducted with a number of recruiters and experts in the digital sphere and about a million lists of requirements to the candidates was analyzed. Based on identified needs, BCG developed a staffing strategy that suggested: (1) identify areas where experts - so-called digital talents - would be most important, and (2) identify ways of finding, engaging and learning.

It is determined that the experts critical for the digital transformation of any business in any industry are: a digital enterprise strategist, who must perform a guiding function at all stages of the functioning of the digital-model; specialist in marketing automation, which, with the help of artificial intelligence technology, provides interaction with consumers online; user interface designer - focuses on creating the interface, user experience of software products and development of the digital potential of the organization; data-scientist, working as an analyst group and detecting hidden relationships and important patterns in the data; SMM manager who must know the basics of marketing, be able to analyze potential consumers, know the basics of sales psychology, evaluate the activity in the social media, use different methods in promoting services through planning, advertising, collaboration with bloggers, etc.

The leaders of change should understand that digital transformation is the construction of a new strategy in which all processes (clients, competition, data, innovations, core values) are digitized and/or transformed in order to improve labor productivity, increase company value, create new jobs, improvement of personal efficiency of employees. All 
these processes lead to an increase in the competitiveness of the economy and, as a result, an increase in the standard of living in Ukraine.

\section{Conclusion}

Summarizing the above, it should be emphasized that Ukraine, having a significant human IT potential, works below its digital capabilities. The measures stipulated by the adopted concepts lay the foundations for the digital transformation, aimed at digitizing business processes. However, accelerated digitalisation, in parallel with the transformation of business models, could add many millions of revenues to the economic growth, additional international investment, and increased international competitiveness. It is necessary to understand that for today the development of digital technologies is inevitable and it depends on us only how effective it will be and in what future we will exist.

\section{References}

1 Global Digital 2019 reports (Hootsuite, $221 \quad$ p., $\quad$ 2019) https://wearesocial.com/blog/2019/01/digital-2019-global-internet-use-accelerates

2 Internet Asotsiatsiia Ukrainy [online], Available at: https://inau.ua/news/oglashenydannye-yssledovanyy-ynternet-audytoryy-ukrayny-za-3-kvartal-2018g

3 David L., Rogers The Digital Transformation Playbook: Rethink Your Business for the Digital Age, Columbia Business School Publishing, Columbia University Press, 296, (2016)

4 Ukrainian Landscape Industry 4.0 Technologies (2019) [online], Available at: https://industry4-0-ukraine.com.ua/2019/05/27/ukrainian-landscape-industry4-0druga-vers\%D1\%96ya/

5 D. Ivanov, A. Dolgui, B.Sokolov. International Journal of Production Research, 57, (2019)

6 IMD World Digital Competitiveness Ranking (IMD World Competitiveness Center, 179, (2018).

7 The World Economic Forum. The Global Competitiveness Report (2018) [online], Internet Asotsiatsiia Ukrainy: http://www3.weforum.org/docs/GCR2018/05FullReport/TheGlobalCompetitiveness Report2018.pdf

8 Rozporiadzhennia Kabinetu Ministriv Ukrainy «Pro skhvalennia Kontseptsii rozvytku tsyfrovoi ekonomiky ta suspilstva Ukrainy na 2018-2020 roky ta zatverdzhennia planu zakhodiv shchodo yii realizatsii» vid 17 sichnia 2018 r. № 67-r. (2018) [online], Available at: https://zakon.rada.gov.ua/laws/show/67-2018-\%D1\%80

9 Tsyfrova adzhenda Ukrainy - 2020 ("Tsyfrovyi poriadok dennyi» - 2020) Kontseptualni zasady (HiTECH Office, 90 p., 2016) [online], Available at: https://ucci.org.ua/uploads/files/58e78ee3c3922.pdf

10 Digital transformation road map in agri-food (2019) [online], Available at: https://agri-food.appau.org.ua/

11 Businessviews [online], Available at: http://publications.chamber.ua/2018/IT/theinfographics-report-it-industry-of-ukraine-2017.pdf

12 Digital BCG. A Digital-People Strategy is Critical in Today's Changing Workplace (2017) [online], Available at: https://www.bcg.com/d/press/19july2017-how-togain-digital-talent-skills-165720. 